\title{
EFISIENSI PENGGUNAAN ELEARNING DENGAN \\ MEMANFAATKAN TEKNOLOGI MOBILE WIRELESS PADA \\ STAIN PAREPARE
}

\author{
Muhammad Ahsan \\ Email: muhammadahsan@stainparepare.ac.id \\ Institut Agama Islam Negeri ( IAIN) Parepare
}

\begin{abstract}
E-learning is formal and informal learning. Formally, the e-learning learning method is carried out using learning that comes from the syllabus. The use of e-learning from lecturers and students at STAIN Parepare is currently still considered not to work well. The interest of students and lecturers in using e-learning is still lacking. This is because the resources of the lecturers in filling the content of the e-learning are still lacking. This study aims to determine the efficiency of using e-learning by using mobile wireless and knowing the level of satisfaction of e-learning users by utilizing mobile wireless.
\end{abstract}

Keywords: E-learning, Moble wireless, Interest

\begin{abstract}
Abstrak
Elearning dapat mencakup pembelajaran secara formal dan informal. Secara formal metode pembelajaran elearning dilakukan dengan menggunakan pembelajaran yang bersumber pada silabus. Penggunaan elearning dari dosen dan mahasiswa pada STAIN Parepare saat ini masih dianggap belum berjalan dengan baik. Minat
\end{abstract}


mahasiswa dan dosen dalam menggunakan elearning masih kurang. Ini disebabkan karena sumber daya dari dosen dalam mengisi kontent dari elearning tersebut masih kurang. Penelitian ini bertujuan untuk mengetahui efisiensi penggunaan elearning dengan memanfaatkan mobile wireless serta mengetahui tingkat kepuasan pengguna elearning dengan memanfaatkan mobile wireless.

Kata Kunci: E-learning, Moble wireless, Minat

\section{PENDAHULUAN}

Secara luas, E-Learning dapat mencangkup pembelajaran secara formal dan informal. Secara formal metode pembelajaran E-Learning dilakukan dengan menggunakan pembelajaran yang bersumber pada Silabus, Rencana Pelaksanaan Pembelajaran (RPP), Satuan Acara Perkuliahan (SAP), dan lain sebagainya yang telah dibuat oleh pengajar maupun siswanya. Sedangkan secara informal metode pembelajaran E-Learning menggunakan perangkat elektronik lain seperti penggunaan mailing list atau e-mail dan juga blog-blog pembelajaran.

Sekolah Tinggi Agama Islam Negeri (STAIN) Parepare sebagai salah satu perguruan tinggi negeri di Indonesia sudah sejak tiga tahun terakhir ini melakukan implementasi dan adaptasi teknologi informasi dan komunikasi. Dengan hadirnya Unit Teknologi Informasi dan Pangkalan Data, prasarana jaringan komputer yang cukup memadai telah terpasang. Hubungan ke jaringan internet, dan layanan berbasis web seperti website dan email juga telah tersedia. Dengan sumber daya manusia teknologi informasi dan komunikasi yang dimiliki lembaga-lembaga di atas, berbagai aplikasi teknologi informasi dan komunikasi juga dikembangkan, diimplementasikan dan telah digunakan hal ini dapat dilihat pada infrastruktur jaringan seperti pada gambar di bawah ini: 


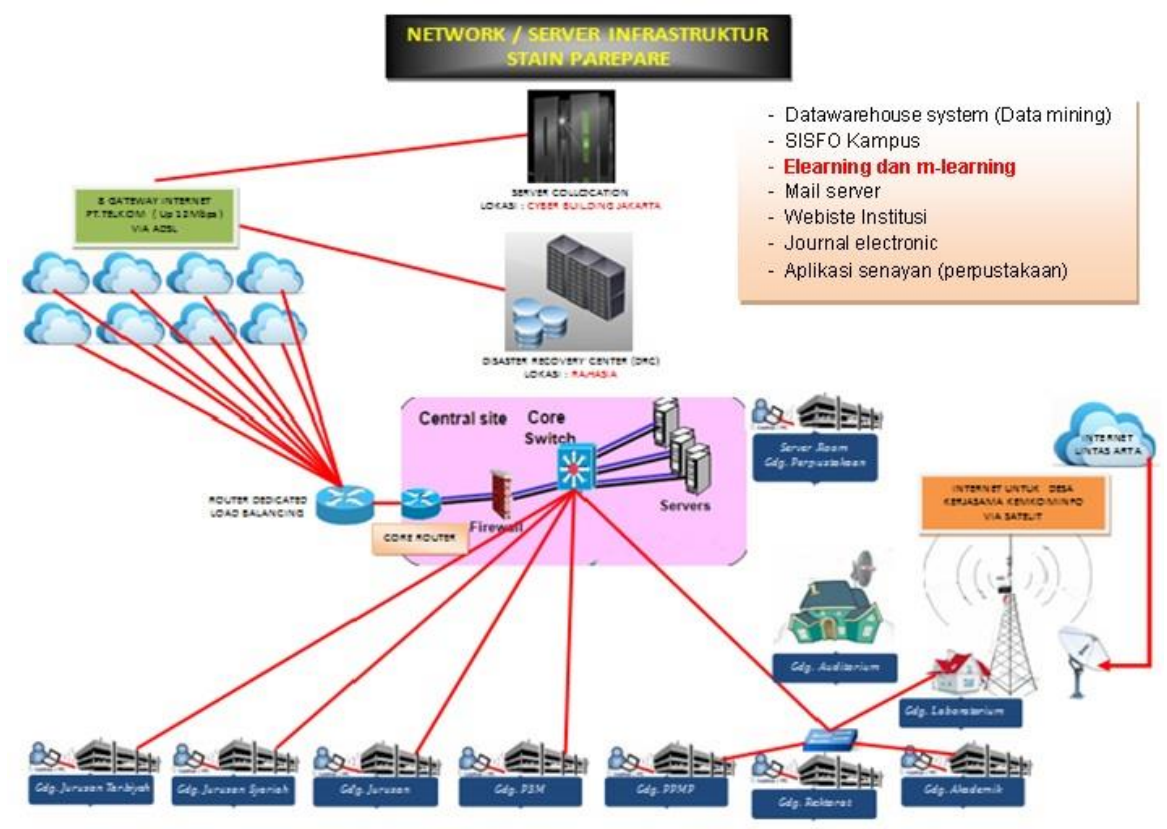

Gambar Infrastruktur Jaringan Fiber Optik STAIN Parepare

Penerapan teknologi informasi dan komunikasi di STAIN Parepare bukan tanpa kendala dan permasalahan. Pengembangan teknologi informasi dan komunikasi masih belum terpadu dengan aktivitas pengembangan lain khususnya dalam proses belajar-mengajar.

Teknologi mobile wireless sudah banyak dikaji oleh peneliti diantaranya Minjuan Wang, Yong Chen, and Muhammad Jahanzaib Khan (2014), dimana mereka mengkombinasikan mobile learning dan cloud computing untuk membantu mengatasi hambatan yang terkait dengan komputasi mobile di Universitas khalifa. Sedangkan Lee W. McKnight and Angela U. Ramnarine-Rieks (2014), menggunakan antena grid dalam dalam pembelajaran interaktif yang mengkoneksikan antara perangkat lunak dan perangkat mobile melalui akses antena grid. Sedangkan Mary Alice Kritsonis and Jan Ray (2041) melakukan 
pengujian penggunaan wireless laptop untuk mendukung penerapan pembelajaran berbasis masalah (PBL).

Sekolah Tinggi Agama Islam Negeri Parepare adalah salah satu perguruan tinggi negeri yang sudah menerapkan konsep pembelajaran e-learning. Konsep ini diterapkan karena tidak ingin adanya hambatan dalam proses belajar mengajar, dengan e-learning belajar mengajar bisa dilakukan kapan saja dan dimana saja selama waktu yang dtentukan masih berjalan.

Kebutuhan akan e-learning semakin besar, sehingga mobilitas user perlu dipertimbangkan. Oleh karena itu, banyak pengembangan yang dilakukan dalam konsep e-learning itu sendiri.

Penggunaan elearning dari dosen dan mahasiswa pada STAIN Parepare saat ini masih dianggap belum berjalan dengan baik. Minat mahasiswa dan dosen dalam menggunakan elearning masih kurang, ini disebabkan karena sumber daya dari dosen dalam mengisi kontent dari elearning tersebut masih kurang. Sementara di kampus sendiri sudah tersedia jaringan mobile wireless yang bisa diakses dalam lingkungan kampus namun masih belum dimanfaatkan dengan maksimal oleh dosen dan mahasiswa. Demikian pula dengan ketersediaan bandwidth untuk mengakses aplikasi elearning sudah memenuhi standar dalam melakukan akses internet.

Berdasarkan latar belakang masalah di atas, maka diperoleh rumusan masalah sebagai berikut:

1. Bagaimana Pemanfaatan mobile wireless yang tersedia?

2. Bagaimana Efisiensi penggunaan elearning dan m-learning?

3. Seberapa besar Kepuasan pengguna (dosen dan mahasiswa) dalam memanfaatkan mobile wireless untuk mengakses elearning dan m-learning? 


\section{Tujuan penelitian:}

1. Mengetahui manfaat mobile wireless yang tersedia

2. Mengetahui efisiensi penggunaan elearning dan m-learning dengan memanfaatkan mobile wireless

3. Mengetahui tingkat kepuasan pengguna elearning dan m-learning dengan memanfaatkan mobile wireless

\section{PEMBAHASAN}

\section{Dampak elearning bagi pengajar dan siswa}

E-Learning merupakan metode pembelajaran yang dipersepsikan berbasis pada student centered, yakni metode pembelajaran yang tertuju pada keaktifan dan kemandirian siswa dalam memahami materi yang diajarkan. E-Learning yang berbasis student centered ini akan membuat mahasiswa membangun pengetahuannya sendiri sehingga mereka mudah memahami materi yang disampaikan dengan pemahaman mereka sendiri.

Dari penerapan E-Learning ini akan berdampak pula pada proses pembelajaran antara pengajar dan siswanya. Berikut merupakan dampak yang dapat ditimbulkan oleh penerapan E-Learning:

\section{Dampak Positif}

\section{Bagi Pengajar}

E-Learning dapat membuat para pengajar dapat mengontrol siswanya melalui tugas yang diberikan melalui internet. Selain itu juga pengajar dapat mengembangkan materi pembelajaran dari manapun, sehingga materi yang diajarkan akan mengembang dan mendetail.

Manfaat lainnya ialah para pengajar tidak akan repot-repot datang terus menerus karena materi yang akan diajarkan sudah di-update pada perangkat 
elektronik yang sudah dikteahui oleh siswanya. Dari sini jugalah para pengajar dapat menemukan metode terbaik dalam proses pembelajaran.

\section{Bagi Siswa}

E-Learning dapat membuat siswa menghemat waktu dalam memperoleh materi yang diajarkan. Siswa jadi tidak harus repot-repot mencari materi untuk memenuhi tugasnya. Selain itu, E-Learning juga dapat membantu siswa ketika tidak hadir di kelas, karena materi yang diajarkan bisa diakses dimanapun dan kapanpun mereka berada, tanpa harus terpaku pada materi yang diajarkan di kelas.

\section{Dampak Negatif}

\section{Bagi Pengajar}

Dengan berkembangnya metode pembelajaran E-Learning, para pengajar menjadi kurang memperhatikan siswanya karena materi yang diajarkan sudah ada di E-Learning. Dengan kata lain para pengajar akan mengurangi perannya sebagai pendidik siswanya, sehingga nilai moral yang ditanamkan akan berkurang dan nilai persaingan akan meningkat.

\section{Bagi Siswa}

E-Learning memang dapat membantu para siswa untuk menyelesaikan tugas yang diberikan. Disisi lain, kualitas tugas yang diberikan akan berkurang karena lebih banyak dihasilkan dari copy-paste materi yang ada sebelumnya. Selain itu juga, bagi siswa yang kurang termotivasi akan malas membuka materi E-Learning yang sudah diberikan oleh pengajarnya, sehingga mereka akan jauh tertinggal materi pelajaran. 


\section{Efektifitas elearning dalam proses pembelajaran}

E-Learning seperti dikatakan diatas memang sangat membantu baik bagi pengajar dalam menyediakan materi pelajaran, maupun bagi siswa dalam mempelajari materi yang diajarkan. Keberadaan E-Learning ini dianggap sangat penting dalam menunjang kurangnya materi pelajaran pada waktu tertentu, misalnya pada saat siswa dispensasi mewakili sekolahnya di ajang tertentu. Karena kesibukkannya latihan sehingga mengorbankan waktunya untuk belajar, siswa tersebut akan ketinggalan materi pelajaran. Untuk itulah E-Learning dapat menjadi alternatif untuk mengejar materi yang tertinggal karena kesibukan latihan.

E-Learning dapat menjadi efektif apabila adanya kerjasama antara pengajar dan siswanya untuk mensukseskannya, tanpa salah satu dari keduanya keberadaan E-Learning tidak akan berjalan secara lancar. Untuk itulah diperlukan komunikasi yang erat antar keduanya. Selain dari itu, efektivitas E-Learning juga didukung oleh keahlian dan kreativitas pengajar dalam meracik materi yang akan disampaikan. Hal ini juga termasuk pada keahlian pengajar dalam mengoperasikan perangkat elektronik.

Terkadang E-Learning juga menjadi beban bagi para pengajar yang belum menguasai operasional perangkat elektronik. Untuk mengatasi permasalahan ini, Dinas Pendidikan terkait banyak melakukan pelatihan bagi guru-guru yang belum menguasai operasional perangkat elektronik, terlebih untuk daerah terpencil.

\section{Efisiensi proses pembelajaran menggunakan elearning}

Untuk memperoleh suatu hal diperlukan suatu biaya untuk mendapatkannya, sama halnya dalam proses pembelajaran. Metode E-Learning dapat menekan biaya yang akan dikeluarkan selama proses pembelajaran, misalnya saja dalam proses mengerjakan tugas. Biasanya dalam mengerjakan tugas siswa diharuskan untuk 
mengerjakannya dalam bentuk Hardcopy dengan mem-print tugasnya tersebut. Akan tetapi dengan adanya E-Learning, tugas pun dapat dikrimkan dalam bentuk Softcopy dengan mengirimkan lewat e-mail. Hal ini tentu dapat menekan biaya untuk membuat tugas.

\section{KESIMPULAN}

Pada intinya, E-Learning memiliki banyak manfaat yang sangat penting abgi proses pembelajaran, tak terlepas dari dampak negatif yang ditimbulkan. Sebagai pengguna E-Learning, sudah sepantasnya kita dapat meninimalisir dampak buruknya tersebut. Dan hal yang tidak kalah penting ialah pemerataan E-Learning di berbagai wilayah terpencil, semoga E-Learning dapat dimanfaatkan oleh berbagai kalangan masyarakat, tidak hanya di daerah perkotaan saja, tapi juga bsia dinikmati di daerah terpencil

\section{DAFTAR PUSTAKA}

Kim, S.H., Mims, C., \& Holmes, K.P. An introduction to current trends and benefits of mobile wireless technology use in higher education. AACE Journal, 14(1), 2006.

Lee W. McKnight and Angela U. Ramnarine-Rieks. Interactive Learning through Wireless Grid. Journal of Applied Learning Technology, Volume 4 No. $1,(2014$.

Minjuan Wang, Yong Chen, and Muhammad Jahanzaib Khan. Mobile Cloud Learning for Higher Education: A Case Study of Moodle in the Cloud. Journal The International Review of Research in Open and Distance Learning, (2014.) 